\title{
The Influence of IIlegal Gold Mining (IGM) on Environmental, Economic, and Educational Sectors of Muara Mensao Village, Jambi
}

\section{Try Susanti, Hidayat, Dewi Sartika, Wiji Utami, Rise Hidayati Viktres, and Devie Novallyan}

State Islamic University Sulthan Thaha Saifuddin, Biology Education, Jl. Jambi Ma. Bulian KM. 16, Jambi, 36657, Indonesia

\section{Abstract}

The influence of Illegal Gold Mining (IGM) on environmental, economic, and education sectors of Muara Mensao Village has been investigated using quantitative and qualitative methods. Muara Mensao Village is a place to collect the first-hand information about IGM. This research examined about the impact and relation of IGM with environmental, economic, and education sectors. The technique of respondents

Corresponding Author:

Try Susanti

trysusanti@uinjambi.ac.id

Received: 19 February 2019

Accepted: 5 March 2019

Published: 16 April 2019

Publishing services provided by

Knowledge E

(c) Try Susanti et al. This article is distributed under the terms of the Creative Commons

Attribution License, which permits unrestricted use and redistribution provided that the original author and source are credited.

Selection and Peer-review under the responsibility of the ICBSA Conference Committee. selection was purposive technique. Furthemore, questionnaire, observation, and literature study were used to collect the data. The combination of qualitative and quantitative methods were used for data analysis. The result of this study exhibited that the activity of IGM gave negative impacts on environmental sector such as appearance of digging hole, disappearance of Semah fish (Tor spp.) population, decrease of forest vegetation, silting of river, and turbid river water. The activity of IGM had economic contribution, which net income for gold miners about 1.500.000-2.500.000 IDR, while for dhompheng machine owners about 5.000.000 IDR. The high income could impact educational sector. The education of young generation in that area showed a good result where among 73 respondents, 30\% are bachelore and master, 11\% are Diploma, $23 \%$ are graduate senior, $15 \%$ are graduate junior, and $21 \%$ are graduate elementary. The activity of IGM gave positive influnces on economic and educational sectors, but it harmed enviromental sector. Consequently, we need serious coorporation among society, government, non government organization, and scientific society to prevent the destruction of natural resources in the future.

Keywords: Amalgamation, Artisanal, Dhompheng machine, Illegal Gold Minning (IGM) 


\section{Introduction}

In Indonesia, exploitation process in several kinds of mining material without govermental permission and without tax is called by Penambangan Tanpa Izin (PETI). The Illegal Gold Mining (IGM) activity happening in Indonesia is included PETI. This term is not only found in Indonesia but also in Ghana namely Galamsey [1, 2], while artisanal of IGM activity in French Guina is called Garimpeiros [3]. The impacts of IGM activity, 
government could not supervise gold production in that territory. Thus so it contributes an unwise exploitation of natural resources, destruction of universe, and state income decrease. The breakage of nature operated by IGM activity was wrong management of unprofessional and uncertified artisanal which is consisted male and female adult even children. They do not apply standardized operating procedure in IGM activity [4, 5]. The IGM activity is a matter of the world in 70 countries, and it is occured in Africa, Asia, and South America [6].

The universe that gets direct impact from IGM activity becomes a fascinating research topic for scientific community to serve as research material in searching of the best solution over the last three decades [7]. Due to the unqualified artisanal in IGM activity, the processes of digging, extraction, and refining of gold lead pollution for environment and ecosystem. The negative impact for environmental sector are abration of land [8], contamination of heavy metal Arcenic (As) and Mercury $(\mathrm{Hg})$ [9], deforestation [10], water pollution, damage of farmlands [11], appearance of big pit [12], decrease of vegetation [13], decay of stream, emergence of social problem [7], cyanide (CN) [14] etc. According Koekkoek (2013), the annual leaching and emision of heavy metal mercury $(\mathrm{Hg})$ in 70 developing counturies by Artisanal Gold Mining (AGM) reaches 1608 tonnes. Thus number showed that those countries use heavy metal heavy metal mercury $(\mathrm{Hg})$ in gold refining process. The environmental quality sagged by IGM activity decreased human health quality such as unhealty air and occuring of deseases. This activity did not only give the negative impact for the environmental sector, but also for the another sector.

The another living sector that gains the influence of IGM activity is economic sector. The artisanal and owner of machine Dhompeng would receive a high profit from this activity, meanwhile the goverment get detriment. Regulated mining is a process that is desired by leader of the country, but that condition is very difficult to be actualized. Indonesia has bulky gold resources, it is linear with the the number of IGM activities in that region [3]. That case was occured in French Guina (South America) when the price of gold increased on 1980s. This condition would be made to induce the regulated and unregulated gold mining processes to be more overactive. This activity almost appear in the countries that have gold recources. Previous study has highlighted gold mining that gold mining could escalate economic sector in Zougnazagmiline and Golgouli [14].

The enhancement of economic sector polarizes educational sector in that area because of the operation of IGM activity. Education becomes one of triumph parameter that region. The high income are utilized to enroll the education of their offspring to get better quality of the education to the level of master degree. As seen from previous 
research, Mancini \& Sala (2018) have declarated that mining activity in territory could impove local infrastucture such as road, energy and water supply and it upgraded quality of health access and education service. Although the IGM activity give positive impact on economic and educational sector, it legacies remain decelarated in several community such as goverment, volunteer of nature, activist, non government organization, and scientific.

This activity took place in Jambi Province. As conducted by Yulianti et. Al. (2016), the IGM activity was operated in Muara Limun Village, Jambi Province. Based on that research result, the Limun River in this area was reducted from 2009 to the last 2015. It was signed by the increasing of heavy metal mercury $(\mathrm{Hg})$ in that river $0,18.10^{-3}$ $\mathrm{mgL}^{-1}$ into $0,3.10^{-3} \mathrm{mgL}^{-1}$ [5]. This phenomenon became a basic in selecting of the research location. Muara Mensao Village was formed in 2006 which was a spliting from Ranggo Village. Generally, the society located in that village came from West Sumatra. The Muara Mensao Village is surrounded by villages such as Ronggo, Tanjung Raden, Monti, and Demang. The region in Muara Mensao Village is about 25-40\% hilly and valley. Batang Limun River also crosses that village and it flows into several rivers such as Kutur, Mensao, Mengkadai, Batang Rebah, Singkut, and Jelapang.

The IGM activity at Muara Mensao Village was started about 2015. The condition of environmental, economic, and educational sectors of Muara Mensao Village was different before the IGM activity started. For environmental sector such as river, forest, and settlement was in good condition. Even though environmental sector was experiencing quality degradation, economic and educational sectors was increasing. Maponga dan Ngorima (2003) have explained that to reduce negative impact in environmental sector, so the society need serious coorporation through education, training, awareness of law or regulation, and coaching of friendly technology $[15,17,18]$. These methods must be conducted to save the earth from destruction and advanced problem.

Based on above describtion, this research was conducted to acquire comprehensive information about the influence of IGM activity on environmental, economic, and education sector in Muara Mensao Village, Jambi Province. The qualitative research is very first study for collecting information about the influences of the IGM activity in Muara Mesao Village.

\section{Materials and Methods}




\subsection{Study area}

This research was conducted in Muara Menao Village, Jambi. The area selection was based on preliminary observation by researcher in that district. After area selection, the researchers limited it into three sectors, environmental, economic, and educational sectors to explore the influence of IGM on these sectors. There were 327 families in Muara Mensao Village and 25 were chosen as respondents. All of respondents were classified into two types, the artisanal and the owner of Dhompeng machine. The data in this study were collected by using questionnaires, observation, and literatur study techniques [19]. The collected data were analyzed by using data reduction, data display, verification, and persentage descriptive entitled in Equation 1.

$$
\frac{\text { Respondent answer }}{\text { The number of respondent }} \times 100 \%=\text { concl.of responden opinion }
$$

\section{Result}

The IGM activity has been conducted by society of Muara Mensao Village by the time so it gave a influence on several living sectors such as environment, economi, and education. The result of this study was attained from respondents. This result was similar to previous study about the effects of gold mining [20-22]. The influence of IGM activity on three living sectors are shown in Table 1, meanwhile Dhompeng machine operation in soil digging for gold collecting in IGM activity is shown in Fig. 1.

TABLE 1: The influence of IGM activity on three of living sectors Muara Mensao Village.

\begin{tabular}{|c|c|c|}
\hline No. & Sectors & Description \\
\hline \multirow[t]{5}{*}{1} & Environmental & a. Lossing of vegetation; \\
\hline & & b. Decreasing of Semah Fish (Tor sp.) population; \\
\hline & & c. Siltation of river; \\
\hline & & d. Turbidy of water river; \\
\hline & & e. Appearance of big pit/hole. \\
\hline \multirow[t]{3}{*}{2} & Economic & $\begin{array}{l}\text { a. Income per month of Dhompeng artisanal } \\
1.500 .000,00 \text { IDR-2.500.000,00 IDR; }\end{array}$ \\
\hline & & $\begin{array}{l}\text { b. Income per month of Dhompeng owner } \\
>5.000 .000,00 \text { IDR; }\end{array}$ \\
\hline & & c. Opening of field oil palm. \\
\hline \multirow[t]{2}{*}{3} & Education & $\begin{array}{l}\text { a. Improvement of education level for young } \\
\text { generation; }\end{array}$ \\
\hline & & b. business opportunity. \\
\hline
\end{tabular}




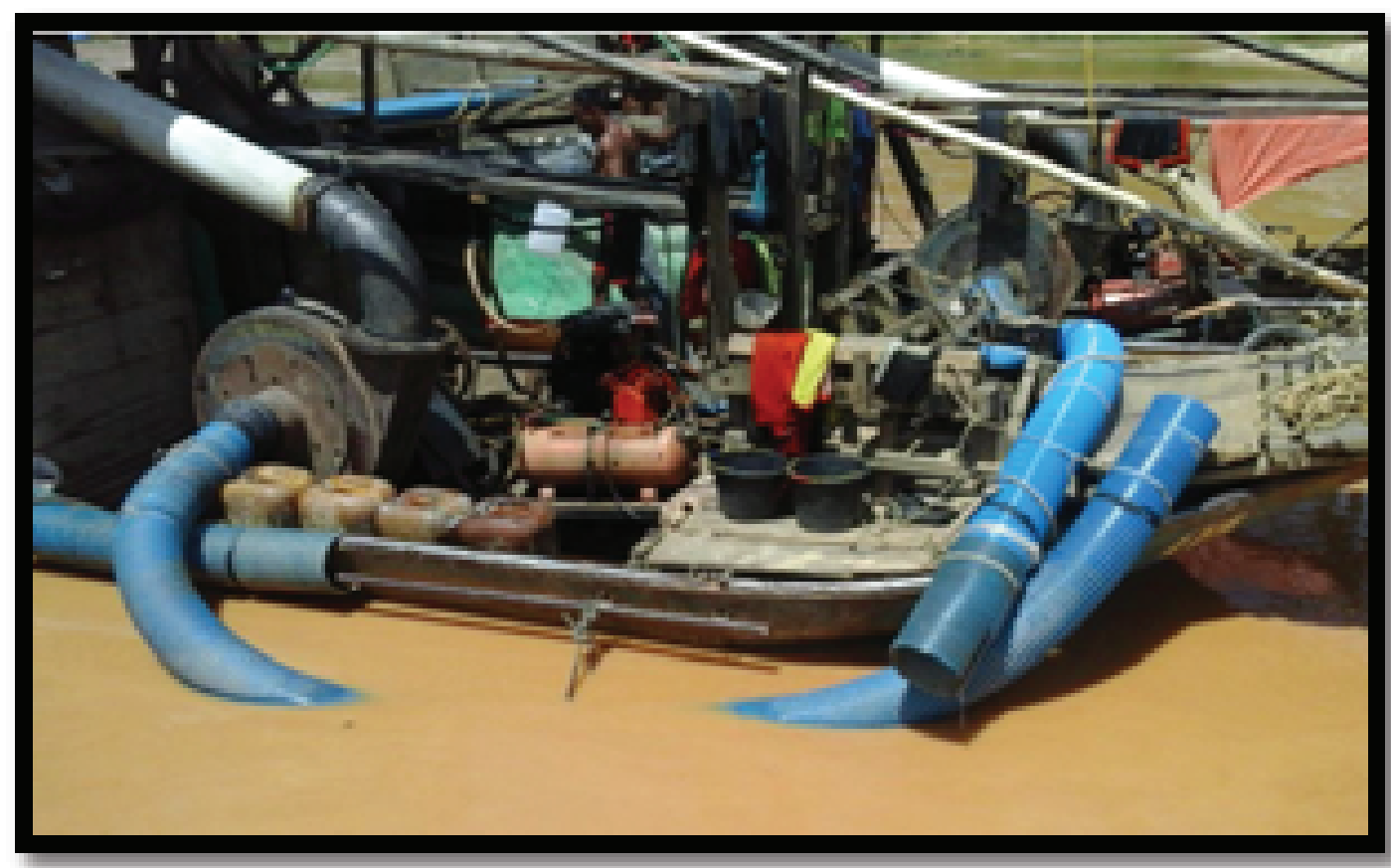

Figure 1: Dhompeng machine for IGM activity in Batang Limun River.

\section{Discussion}

\subsection{Environmental sector}

Mining is one of industrial sector and it was highly potential for environmental pertubation [2, 3, 11, 12, 19, 23, 24]. Nowadays, this situation is getting a special notice from scientific community for being their research topic. The IGM activity became an exclusive duty for Energy and Mineral Resources Department in Indonesia so they have to coorperate with all elements of society for problem solving. The IGM activity located in Muara Mensao Village gave influences to sector living and they were described in Table 1. The IGM activity conducted by artisanal and owner Dhompeng machine caused a dictruction of soil and water ecosystem. The detailed information of environmental distrubtion on Muara Mensao Village caused the IGM activity was obtained from respondents.

Based on observation and interview, in the ecosystem of water, the IGM activity polluted river water so this situation disturbed Semah Fish (Tor sp) population. Semah Fish (Tor sp) is the most expensive fish which is demanded by socienty in Jambi Province. Nowadays, the IGM activity not only disturb Semah Fish (Tor sp) population, but also causes extinction of the fish. The disappearance of the Semah Fish could decrease income of fisherman in that district. The extraction and purification of gold do not only 
harm fish population but also trigger the mercury gravitated in its body.The previous study explained that fish found in near gold extraction in North Sulawesi's Minahasa Peninsula contained high concentration of mercury [21].

The IGM activity in headwater of river can cause unstable condition in the river. The purification of gold would dispose waste to the surrounding of environment, e.g., river. That waste advanced the turbidity of water river. Advanced turbidity in the water can polarize the temperature of water. The surface of the river would be warmer. Fish could live properly in temperature $27-33^{\circ} \mathrm{C}$. At high temperature, the fish would undergo high respiration which was noticed by appearance of fish in the surface of water to get more oxygen $\left(\mathrm{O}_{2}\right)$. While at low temperature, this condition could slow their activities. The temperature is one of the important factors that influence the biota in Batang Limun River. This observation is in agreement with the previous study [25]. The temperature fluctuation of river could be attributed by waste disposal. It disturbed the paramaters of water quality such as Total Dissolved Solution (TDS), Total Solid Suspended (TSS), and Oxygen Demand (OD).

The IGM activity did not only interfere the population of Semah Fish but also led harm on plant biodiversity in that region. That condition was marked by the decreasing of plant vegetation. A few years ago, that region had primary forest, which were converted by society becaming rubber field. Since the IGM activity was started in that region, the rubber field was changed into the IGM field. This result is in approval with the previous study $[13,26]$.

Based on the results of interview with the society in Muara Mensao Village as respondents, there were among those who were aware the negative impact of IGM activity for environmental sector. They explained the real impact that we could see the large hole at the surface of land. The holes could not get a wise treament after IGM activity. On the other side, some of resondents did not know the negative impact of IGM activity for environmental sector. They thought all this time, they have disposed mercury waste away from settlement so it did not give a negative impact to the environmental sector. From the description above, most of the community did not understand about Good Mining Practice and they require training and coaching from the government $[4,7,15,27]$. The previous study told, since training and coaching for the miners were conducted, they understood that their rudimentary process in extraction ore were very harmfull and forbidden by law [27]. Currently, the land near the settlement was nothing left so the IGM activity was contiuned in the forest, 3-5 km from the settlement. The effect of IGM operation to Batang Limun river was shown at Fig. 2. 


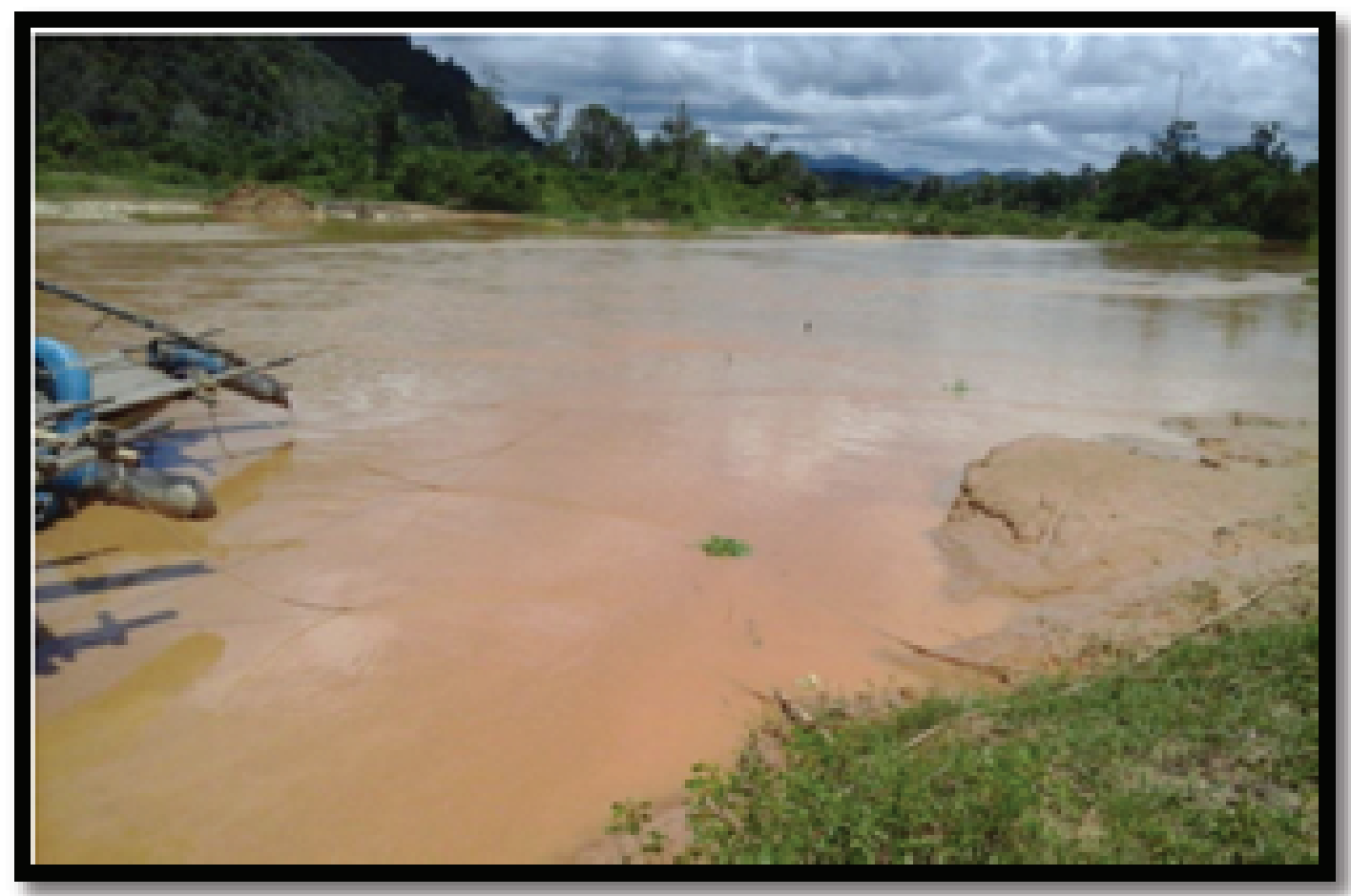

Figure 2: Batang Limun River experienced broadening and silting (Source: private document, 2017).

The colour of Batang Limun River water is brown and turbid so the water could not be used by society for bathing, washing, cooking, and drinking (see Fig. 2). The level water turbidity can accelerate the silting of river. For instance, the fine material that were suspended in water precipitated in the bottom of river [8]. This result was in convinient with previous study that the Batang Limun River has been experiencing physical and chemical alteration. This indication can be seen from the change of water colour from limpid into brownish turbid. In Batang Limun River was found heavy metals such as $\mathrm{Pb}$, $\mathrm{Cu}, \mathrm{Zn}, \mathrm{Mn}$, and $\mathrm{Hg}$. Observation for the river was carried out from 2009-2015. It focused on before and after the IGM activity. The concentrations of Mercury were 0.18-0.30 ppb. Whilst, the highest concentration of mercury was 153 ppb [5]. The heavy metal content was very dangerous for living things $[28,29]$.

The IGM activity has disadvantages such as contavention of Good Mining Practice in operation, non renewable resources, and distruption of environmental. That activity is adversed for all of the kind of society and the future generation [30, 31]. That operation was begun with the making of the big hole using Dhompheng machine that was depicted in Fig. 3. The artisanal was digged the land using Dhompheng machine, 20-24 K (see Fig. 3 a,b). That machine with that power can make hole about $5 \mathrm{~m}^{2}$ per day. Unfortunetely, the land which did not generate the ore of gold would be left 

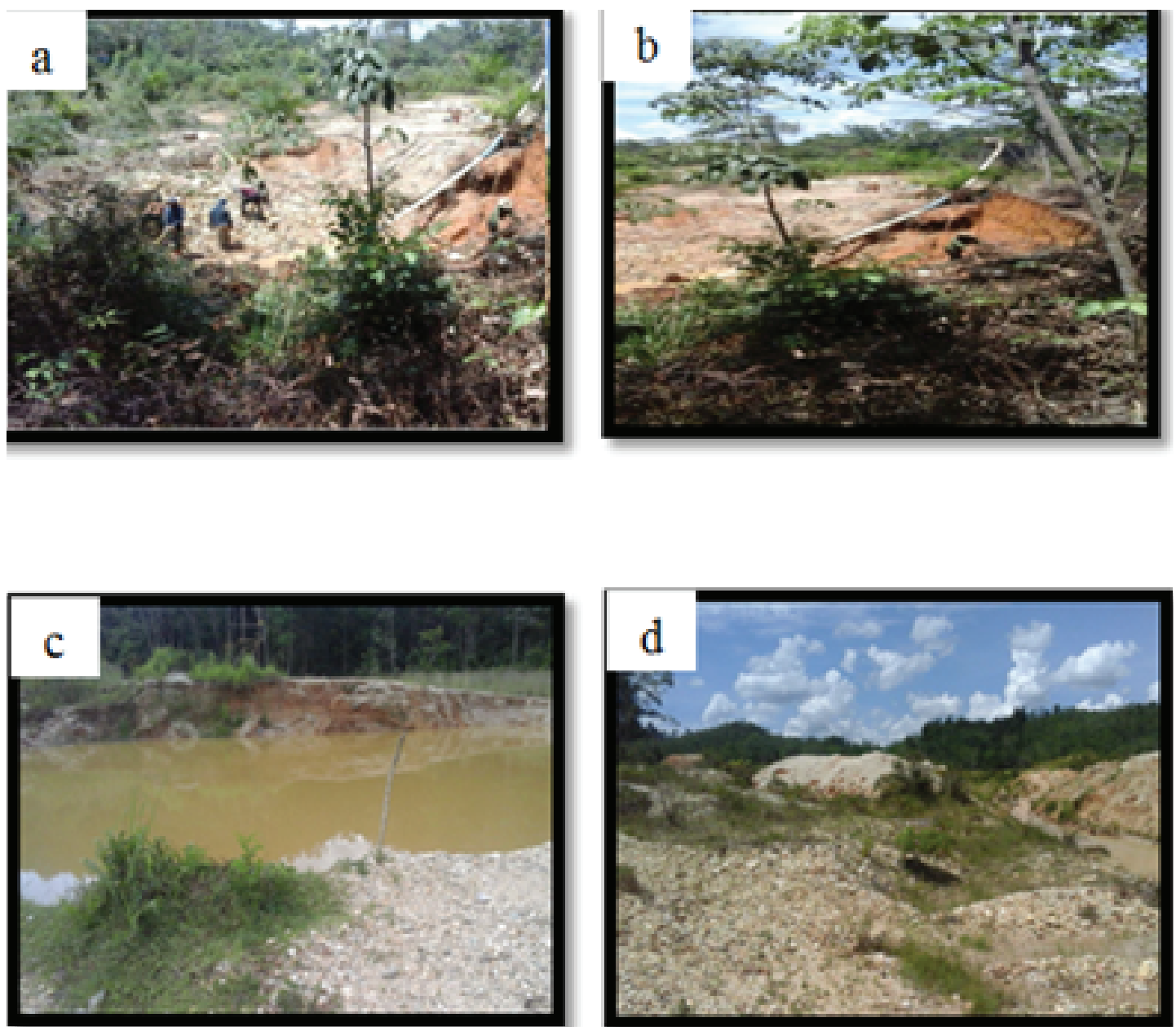

Figure 3: a. The artisanal digged the soil using Dhompheng machine; b. The resulted a big hole; $c$. The hole resembling lake in rainy season; d. Bulk density (Source: Private data, 2017).

without restoration and reclamation. The effect of this unwise activity yielded the big hole resembling lake. It was summarized in Fig. 3 c.

The restoration process of the fertility soil can occur naturally but it is time comsuming. It is imbalance between distruction and restoration. The negative impacts of the IGM activity were seen on Fig. 3.d. The soil encountered bulk density furthemore occured loss of soil nutrient, decreasing of $\mathrm{pH}$ soil and microba population. The previous research explained that this operation needed the regulations managing the miners to restore the area after the IGM operation. It can save the environment from distruction in the future [17].

Based on description that were summarized in Table 2, the IGM operation in Muara Mensao Village destroy environment. The amalgamation process is very harmfull tecnique because it can leach mercury to the water and land [11, 19, 32, 33]. Zolnikov and Ortiz (2018) desribed that the amalgamation can be replaced by using friendly and inexpensive methods, such as cyanidation, magnet, direct smelting, and borax. Using 
TABLE 2: Respondent's opinion about environmental distraction due to the IGM activity in Muara Mensao Village, Sarolangun.

\begin{tabular}{|c|c|c|c|c|c|c|c|}
\hline \multirow[t]{2}{*}{ No. } & \multirow[t]{2}{*}{ Description } & \multicolumn{5}{|c|}{ Percentage(\%) } & \multirow[t]{2}{*}{ Total } \\
\hline & & VA & $A$ & LA & $D$ & SD & \\
\hline 1. & $\begin{array}{l}\text { The IGM operation will influence the } \\
\text { environmental quality. }\end{array}$ & 0 & 44 & 44 & 12 & 0 & 100 \\
\hline 2. & $\begin{array}{l}\text { The IGM operation will support environmental } \\
\text { conservation. }\end{array}$ & 0 & 56 & 32 & 12 & 0 & 100 \\
\hline 3. & $\begin{array}{l}\text { The IGM operation will not effect } \\
\text { environmental quality. }\end{array}$ & 0 & 60 & 24 & 16 & 0 & 100 \\
\hline 4. & $\begin{array}{l}\text { The IGM operation will cause environmental } \\
\text { pertubation. }\end{array}$ & 0 & 44 & 44 & 12 & 1 & 100 \\
\hline 5. & $\begin{array}{l}\text { The IGM operation will cause the silting of the } \\
\text { river }\end{array}$ & 0 & 48 & 32 & 20 & 0 & 100 \\
\hline 6. & $\begin{array}{l}\text { The IGM operation will cause the turbidity of } \\
\text { river. }\end{array}$ & 32 & 48 & 20 & 0 & 0 & 100 \\
\hline 7. & $\begin{array}{l}\text { The IGM river can not be used as clean water } \\
\text { supply. }\end{array}$ & 0 & 24 & 52 & 24 & 0 & 100 \\
\hline 8. & $\begin{array}{l}\text { The ex-excavation land will not to be used for } \\
\text { agricultural land. }\end{array}$ & 0 & 12 & 60 & 28 & 0 & 100 \\
\hline 9. & $\begin{array}{l}\text { The IGM operation damages the agricultural } \\
\text { land. }\end{array}$ & 0 & 32 & 44 & 24 & 0 & 100 \\
\hline \multicolumn{8}{|c|}{ (Source= primary data) } \\
\hline \multicolumn{8}{|c|}{ Explanation: } \\
\hline \multicolumn{8}{|c|}{ VA = Very Agree } \\
\hline \multicolumn{8}{|c|}{$A=$ Agree } \\
\hline \multicolumn{8}{|c|}{ LA = Less agree } \\
\hline \multicolumn{8}{|c|}{$D=$ Disagree } \\
\hline $\mathrm{SD}=$ & trongly disagree & & & & & & \\
\hline
\end{tabular}

cyanadation in gold extraction can obtain the gold up to $95 \%$ in $8 \mathrm{~h}$ compared to using mercury [20].

\subsection{Economic sector}

The economic sector is the important sector for living of human being and has relation with another sector. The perception respondent about increasing of economic sector were clearly explained. The IGM activity gave high effect on economic sector in that region. Economic condition can be learn from several aspects, such as job vacancy, income, education level, and saving opportunity [19, 24, 34]. Since the selling price of rubber comodities declined, the society of Muara Mensao Village fulfilled economic necesary by conducting IGM activity as artisanal and owner. Nowadays, in that district there are 30 units of Dhompheng machine whereas 1 is operated by 3-8 artisanals. The 
artisanal of Dhompheng machine is originated from inside and outside of the village for monthly income.

TABLE 3: Income per month of Muara Mensao Village Society.

\begin{tabular}{l|l} 
No. & Income per month (IDR) \\
\hline 1. & $<1.500 .000,00$ \\
\hline 2. & $1.500 .000,00-2.500 .000,00$ \\
3. & $2.500 .000,00-3.500 .000,00$ \\
4. & $3.500 .000,00-4.500 .000,00$ \\
\hline 5. & $>5.000 .000$ \\
Amount
\end{tabular}

\begin{tabular}{|c|}
\hline Respondents \\
\hline 0 \\
\hline 11 \\
\hline 0 \\
\hline 0 \\
\hline 14 \\
\hline 25 \\
\hline
\end{tabular}

$\begin{gathered}\text { Percentage } \\ (\%)\end{gathered}$
0
44
0
0
56
100

The incomes of society from IGM activity were listed in Table 3. Among the artisanal (respondents) 44\% earn 1.500.000,00-2.500.000,00 IDR a month. Furthemore, the income obtined from IGM activity was used for starting of business such as restaurant, garage, bike or car wash, and cattle. This activity created new jobs and they can lift a life quality. The previous study reported the effect of temporary closures of mining in Quang Nam Province (Vietnam) led unemployment and tax debts [24]. Viega et al. (2014) said that the government have to hold a training and coaching for local miner to upgrade their knowledge in gold extraction, cure the environment, and ecosystem conservation [35].

TABLE 4: The opinions of repondent about the impact of the IGM activity to economic sector in Muara Mensao Village, Sarolangun.

\begin{tabular}{|c|c|}
\hline No. & Description \\
\hline 1. & $\begin{array}{l}\text { The IGM activity will open job opportunity for } \\
\text { the community. }\end{array}$ \\
\hline 2. & $\begin{array}{l}\text { The miner must Para pekerja diutamakan dari } \\
\text { warga tetap. }\end{array}$ \\
\hline 3. & $\begin{array}{l}\text { The IGM activity IGM can improve income a } \\
\text { month. }\end{array}$ \\
\hline 4. & The IGM activity brings blessing. \\
\hline 5. & The IGM activity can open other business. \\
\hline 6. & The IGM activity can benefit the community. \\
\hline 7. & The IGM activity is the main livehood. \\
\hline 8. & The IGM activity can satisfy household needs. \\
\hline 9. & $\begin{array}{l}\text { The IGM activity can improve the savings of } \\
\text { community. }\end{array}$ \\
\hline 10. & $\begin{array}{l}\text { The IGM activity can increase the purchasing } \\
\text { power to Sekunder goods i.e., car, } \\
\text { motorcycle, electronic devices. }\end{array}$ \\
\hline
\end{tabular}

\begin{tabular}{|c|c|c|c|c|c|}
\hline \multicolumn{5}{|c|}{ Percentage (\%) } & Total \\
\hline VA & A & LA & D & SD & \\
\hline 24 & 64 & 8 & 4 & 0 & 100 \\
\hline 8 & 20 & 60 & 12 & 0 & 100 \\
\hline 36 & 24 & 12 & 0 & 0 & 100 \\
\hline 24 & 68 & 8 & 0 & 0 & 100 \\
\hline 32 & 60 & 8 & 0 & 0 & 100 \\
\hline 36 & 56 & 8 & 0 & 0 & 100 \\
\hline 20 & 76 & 4 & 0 & 0 & 100 \\
\hline 0 & 95 & 5 & 0 & 0 & 100 \\
\hline 12 & 84 & 9 & 4 & 0 & 100 \\
\hline 16 & 52 & 32 & 0 & 0 & 100 \\
\hline
\end{tabular}


To find out more information about the effects of IGM activity to economic sector in Muara Mensao Village, the questionaire data obtained were listed in Table 4. As seen in Table 4, questions 1, 2, 3 and 7 related with jobs and income opportunity. The majority of the respondent in that region (96\%) assumed that the IGM activity as the source of society livehood. Questions 4, 5, and 6 related with the IGM activity and other business. Because the income from IGM activity is valuable, it can be utilited for creating a new businesses. In addition, 92\% respondents agreed that the IGM activity brought other blessing in their lives e.g., opening of another business. Afterward, questions 8, 9, and 10 , the people explained that they could buy secondary needs such as electronic devices, motorcycles, cars, houses, and etc. The IGM activity in this district can improve economic sector but it give negative impact to environmental sector. It will be duty togovernment and society for thinking to find the best solution to cure this case. This result is in agreement with the previous study that the IGM operation lifted income a month of inhabitants in certain area. They could buy anything that they wanted [32].

\subsection{Education sector}

The improvement of economic sector in Muara Mensao Village directly affects the educational sector in that region [7, 14, 36, 37]. This sector is important to be learn because it is one of the triumph parameter. The development of educational sector in Muara Mensao Village is not yet maximum. It can be marked by lack of infrastructure which causes the young generation from this village continue thei education in other areas. The infrastuctures found in Muara Mensao Village is summarized in Table 5.

TABLE 5: The education infrastructure in Muara Mensao village.

\begin{tabular}{l|l} 
No. & Education Infrastructure \\
\hline 1. & Kindergarten \\
\hline 2. & Elementary School \\
3. Junior High School \\
Total
\end{tabular}

\begin{tabular}{|c|}
\hline Amount \\
\hline 1 \\
\hline 1 \\
\hline 1 \\
\hline 3 \\
\hline
\end{tabular}

As seen at Table 5, the education infrastructure in that village is not enough for compliance of education at that level. For getting higher education, the parents prefer their children to go to other area. This way needed the cost to pay everything such as lodging, monthly expense, charge, and etc. Based on the interview result were collected that the IGM activity helped educational necesity for their children. The recapitulation of education level of respondent's children were listed in Table 6. 
TABLE 6: The education level of respondent's children.

\begin{tabular}{l|c|}
\hline No. & Level of education \\
\hline 1. & Elementary school \\
\hline 2. & Junior High School \\
\hline 3. & Senior High School \\
\hline 4. & Diplomas \\
\hline 5. & Undergraduate/Mater \\
\hline Total & \\
\hline
\end{tabular}

\begin{tabular}{|c|}
\hline Respondents \\
\hline 15 \\
\hline 11 \\
\hline 17 \\
\hline 8 \\
\hline 22 \\
73 \\
\hline
\end{tabular}

\begin{tabular}{|c|}
\hline Percentage(\%) \\
\hline 21 \\
15 \\
23 \\
\hline 11 \\
\hline 30 \\
100 \\
\hline
\end{tabular}

Based on Table 6, it can be seen that number of their children reaching the undergraduate or master degree was 22 people. This was the best development for young generation. The young generations who get the best education could develop their village in the future. The transformation of education level of the society in this village could be measured from their educational level that is related to social aspect. The impact of the IGM activity to educational sector could be quantified using percentage appraisal and their answers were listed in Table 7.

Among respondents, $85 \%$ said that the infrastructure of education sector in their village was stagnan, there was not improvment and building of the infrastructure in the past few years. Not only that, $80 \%$ claimed that the quality of teacher in that schools did not have any progress.

TABLE 7: The opinions of repondent about the impact of the IGM activity to education sector in Muara Mensao Village, Sarolangun.

\begin{tabular}{|c|c|c|c|c|c|c|c|}
\hline \multirow[t]{2}{*}{ No. } & \multirow[t]{2}{*}{ Description } & \multicolumn{5}{|c|}{ Percentage (\%) } & \multirow[t]{2}{*}{ Tota } \\
\hline & & VA & A & LA & D & SD & \\
\hline 1. & $\begin{array}{l}\text { The avalaibility of the educational } \\
\text { infrastructure. }\end{array}$ & 0 & 15 & 60 & 25 & 0 & 100 \\
\hline 2. & The improvement of teachers. & 0 & 20 & 52 & 28 & 0 & 100 \\
\hline 3. & $\begin{array}{l}\text { The ability to pay the better school } \\
\text { requirements. }\end{array}$ & 15 & 85 & 0 & 0 & 0 & 100 \\
\hline 4. & The ability to buy better school books. & 10 & 90 & 0 & 0 & 0 & 100 \\
\hline 5. & $\begin{array}{l}\text { The young generation can continue thei } \\
\text { education level to the higher level. }\end{array}$ & 8 & 88 & 4 & 0 & 0 & 100 \\
\hline 6. & The upgrading of the school infrastrucutre & 0 & 28 & 20 & 52 & 0 & 100 \\
\hline
\end{tabular}

The alteration of social aspect showed that they could provide the equipments of school for their children such as book, uniform, motorcycle and etc. This explanation was extracted from the interview question 3,4 , and 5 . The society agreed if the infrastructures of education must be expanded for reaching the best quality of education level. This result is in agreement with the previous study. The presence of the IGM operation 
in certain territory can facillitate the local inhabitants to access better education level [16].

\section{Conclusion}

The IGM activity in Muara Mensao Village by artisanal of mining influences the environmental, economic, and education sectors. All of the influence is experienced by local community.

1. For environmental sector, this phenomena give negative influence such as the damage of forest vegetation, distraction of land surface, broadening and silting of the river, turbidity of river water, interruption of Semah Fish population, and forming of big hole resembling lake in rainy season.

2. For economic sector gives positive impact e.g., the increasing of income per month. The owner of Dhompheng machine earn $>5.000 .000$ IDR a month while the artisanals of mining earn 1.500.000IDR a month.

3. Their offspring could continue their level of education in higher degree so it could became to develop the village in the future. Nowadays, education sector is required big attention from government because it is one of the success parameter in any country for better life.

The positive impacts on economic and education sectors obtained were imbalanced with negative impact to the environmental sector. Post-treatment to the land after the IGM activity was needed to restore the condition of the nature. Furthemore the government must sharp the implementation of constitution of mining to ensure the quality of natural resourches. This study could be continued by using quantity method, e.g., analysis of heavy metal using chemical equipment.

\section{Acknowledgements}

The researchers thank to Zainuri Anwar, M.Eng., Awliya Rahmi, M.Hum., Center for Educational Development (CED) forum in State Islamic University Sulthan Thaha Saifuddin Jambi, Forum Dosen Indonesia (FDI) Jambi, and Ika Nur Fitriani, M.Sc. for the discussion about this article. 


\section{References}

[1] F. Owusu-Nimo, J. Mantey, K.B. Nyarko, E. Appiah-Effah, A. Aubynn, Heliyon 4 (2018) $1-36$.

[2] R. Dutu, Energy Policy 98 (2016) 513-519.

[3] M. Douine, E. Mosnier, Q. Le Hingrat, C. Charpentier, F. Corlin, L. Hureau, A. Adenis, Y. Lazrek, F. Niemetsky, A.L. Aucouturier, M. Demar, L. Musset, M. Nacher, BMC Public Health 18 (2017) 1-10.

[4] T.R. Zolnikov, Sci. Total Environ. 419 (2012) 1-6.

[5] R. Yulianti, E. Sukiyah, N. Sulaksana, Bull. Sci. Contrib. 14 (2016) 251-262.

[6] K.H. Telmer, M.M. Veiga, in:, Springer, 2008, pp. 131-132.

[7] J. Rochlin, Extr. Ind. Soc. (2018) 0-1.

[8] L. Tudesque, G. Grenouillet, M. Gevrey, K. Khazraie, S. Brosse, Ecol. Indic. 14 (2012) 100-106.

[9] T. Shepherd, I. Rumengan, A. Sahami, Mar. Environ. Res. (2018).

[10] R. Ranjan, Resour. Policy (2018) 1-15.

[11] K.J. Bansah, N.K. Dumakor-Dupey, E. Stemn, G. Galecki, Resour. Policy (2018) 0-1.

[12] F. Winde, F. Kaiser, E. Erasmus, Renew. Sustain. Energy Rev. 78 (2017) 668-682.

[13] T. Zvarivadza, A.S. Nhleko, Resour. Policy (2017) 0-1.

[14] L. Christine, H. Anderson, H. Karoui, J. Podgorski, H. Yacouba, Catena 162 (2018) 40-50.

[15] B. Koekkoek, Meauring Global Progress towards a Transition Away from Mercury Use in Artisanal and Small-Scale Gold Mining, 2013.

[16] L. Mancini, S. Sala, Resour. Policy (2018) 1-14.

[17] O. Maponga, C.F. Ngorima, 11 (2003) 147-157.

[18] D. Avcl, (2015).

[19] M.M. Veiga, G. Angeloci-Santos, J.A. Meech, Extr. Ind. Soc. 1 (2014) 351-361.

[20] T. Rava, D. Ramirez, Sci. Total Environ. 633 (2018) 816-824.

[21] J.L. Kambey, A.P. Farrell, L.I. Bendell-Young, Environ. Pollut. 114 (2001) 299-302.

[22] A. Rettberg, J.F. Ortiz-Riomalo, World Dev. 84 (2016) 82-96.

[23] E. Yanuar, Suprapto, Procedia Chem. 17 (2015) 59-65.

[24] B.N. Nguyen, B. Boru, M. Tonts, Resour. Policy (2018).

[25] G.A.H. Sallam, E.A. Elsayed, Ain Shams Eng. J. 9 (2018) 1-14.

[26] A. Rixen, S. Blangy, Extr. Ind. Soc. 3 (2016) 297-312. 
[27] M.M. Veiga, G. Angeloci, W. Ñiquen, J. Seccatore, J. Clean. Prod. 94 (2015) 268-277. [28] J.G. Martinez, M.A. Torres, G. dos Santos, T. Moens, Ecol. Indic. 91 (2018) 712-721.

[29] R. Xiao, S. Wang, R. Li, J.J. Wang, Z. Zhang, Ecotoxicol. Environ. Saf. 141 (2017) 17-24.

[30] S. Spiegel, Land Use Policy 54 (2016) 559-573.

[31] J.D. Langston, M.I. Lubis, J.A. Sayer, C. Margules, A.K. Boedhihartono, P.H.G.M. Dirks, Extr. Ind. Soc. 2 (2015) 434-444.

[32] A.G.N. Kitula, J. Clean. Prod. 14 (2006) 405-414.

[33] D. Limbong, J. Kumampung, J. Rimper, T. Arai, N. Miyazaki, Sci. Total Environ. 302 (2003) 227-236.

[34] Y.T. Male, A.J. Reichelt-Brushett, M. Pocock, A. Nanlohy, Mar. Pollut. Bull. 77 (2013) $428-433$.

[35] M.M. Veiga, G. Angeloci, M. Hitch, P. Colon Velasquez-Lopez, J. Clean. Prod. 64 (2014) 535-544.

[36] Z.T. Orozco, M. Veiga, Extr. Ind. Soc. (2018) 0-1.

[37] B. Aguilar-gonzález, G. Navas, C. Brun, A. Aguilar-umaña, P. Cerdán, Extr. Ind. Soc. (2018) 0-1. 